\title{
FIRST RECORD OF HYDROGONIUM GREGARIUM (POTTIACEAE, BRYOPHYTA) IN RUSSIA: AN INTERESTING EXTENSION OF THE SPECIES' DISTRIBUTION TO THE HEART OF THE PERMAFROST ZONE
}

\author{
Elena A. Ignatova, Jan KuČERA, OXANA I. KuZNETSOVA \\ \& MiCHAEL S. IGNATOV
}

\begin{abstract}
Hydrogonium gregarium (Mitt.) Jan Kučera, previously known from Southeast Asia, Japan, and scattered occurrences in Pacific North America south to Mexico, is reported for the first time in Russia from the central part of Yakutia at the western foothills of the Verkhoyansk Range. Both morphology and nuclear ITS sequence data confirm its identity with H. gregarium var. gregarium. The species is described and illustrated, and its habitat is briefly discussed.
\end{abstract}

Key words: Pottiaceae, Hydrogonium, taxonomy, phylogeny, barcoding, phytogeography, disjunction

Elena A. Ignatova, Biological Faculty, Moscow State University, Moscow119234 Russia; e-mail: arctoa@list.ru Jan Kučera, Department of Botany, Faculty of Science, University of South Bohemia, Branišovská 31, 37005 České Budějovice, Czech Republic; e-mail: kucera@prf.jcu.cz

Oxana I. Kuznetsova \& Michael S. Ignatov Tsitsin' Main Botanical Garden of the Russian Academy of Sciences, Botanicheskaya 4, Moscow127276Russia; e-mails: oikuznets@gmail.com \& misha_ignatov@list.ru

\section{INTRODUCTION}

Recent studies of the moss flora of Yakutia have yielded many interesting and highly unexpected findings. Many xerophytic plants, including Hilpertia velenovskyi (Schiffn.) R. H. Zander, Syntrichia caninervis Mitt., Jaffueliobryum latifolium Thér. and Indusiella thianschanica Broth. \& Müll. Hal., whose main distribution range is in more southern regions, were found above the Polar Circle here (Ivanova et al. 2005; Isakova 2010). Findings of mesophytic Brachythecium buchananii at $61^{\circ} \mathrm{N}$ (Krivoshapkin et al. 2001) and hygrophytic Philonotis falcata at $63^{\circ} \mathrm{N}$ (Koponen et al. 2012) are also noteworthy. This paper adds one more remarkable new record for the region.

One of the Yakutian sites surveyed in 2011 was near Teplyj Klyuch settlement at the western foothills of the Verkhoyansk Range, at $63^{\circ} \mathrm{N}$. This is a very cold place, with permafrost $\mathrm{ca} 500 \mathrm{~m}$ deep, $+17^{\circ} \mathrm{C}$ mean July temperature, $-36^{\circ} \mathrm{C}$ mean January temperature and minima reaching $-64^{\circ} \mathrm{C}$
(Lazebnik 2000). The area is essentially lowland covered by Larix forest alternating with peatlands. Slightly more diverse flora can be found near rivers, as was the case along the Vostochnaya (= Eastern) Khandyga River, a tributary of the Aldan River, which empties into the Lena River. At the edge of an extensive gravelly bar before a terrace with Larix forest is a sandy bank 1-2 m high (Fig. 1). There are a few mosses on these sandy-silty banks, including Bryoerythrophyllum recurvirostrum (Hedw.) P. C. Chen, Encalypta sp. div., Distichium capillaceum (Hedw.) Bruch \& Schimp., Polytrichum juniperinum Hedw. and Ceratodon purpureus (Hedw.) Brid. Having collected small gemmiferous Barbula-like plants, at first we did not expect anything promising, as the overall moss diversity seemed poor.

Upon microscopic examination, however, in these specimens we found that the dorsal surface of the costa shows papillae at the cell joints, 
a characteristic of southern Hydrogonium species of the H. orientale group (sensu Kučera et al. 2013). The combination of costa papillosity with large $(>150 \mu \mathrm{m})$, beaked, multicellular ovoid gemmae indicated its identity with Barbula gregaria (Mitt.) A. Jaeger, B. indica var. gregaria (Mitt.) R. H. Zander, or B. horrinervis K. Saito by different authors (Saito 1975; Köckinger \& Kučera 2007; Zander 2007). Kučera et al. (2013) have now established that this taxon belongs within Hydrogonium. However, they also found, based mainly on molecular grounds, that the principally central american taxon $H$. cruegeri (Sond. ex Müll. Hal.) Jan Kučera, should be maintained at specific level, although its morphological separation from $H$. gregarium is problematic. This uncertainty required genotyping the Yakutian plants; the nrITS sequence was obtained to verify the plant's identity. The data also enabled comparison with the known sequence of Hydrogonium gregarium var. gallinulum (R. H. Zander) Jan Kučera (Barbula convoluta var. gallinula R. H. Zander), the northernmost known taxon of this complex, with stations in Alaska, the Canadian Northwest Territories and British Columbia (Zander 2007). The latter variety differs from the Yakutian and other plants of $H$. gregarium by its larger leaf cells (10-12 $\mu \mathrm{m})$ and costa ending below the apex, while var. gregarium has cells only $7-10 \mu \mathrm{m}$ and mostly percurrent costa.

\section{MATERIAL AND METHODS FOR MOLECULAR STUDY AND PHYLOGENETIC ANALYSIS}

The ITS sequence (ITS1-5.8S rDNA-ITS2 nuclear region) was obtained from herbarium material by standard DNA extraction, amplification and sequencing protocols as described by Gardiner et al. (2005). The GenBank accession number for this sequence is KC995170. The choice of ITS as barcoding marker has repeatedly proved useful due to its phylogenetic informativeness at the lowest taxonomic levels; it was one of the three markers used in a recent study of Hydrogonium and related taxa (Kučera et al. 2013). The ITS of a Mexican accession of $H$. gregarium analyzed in that study showed a closer relation to $H$. cruegeri as opposed to the signal from the chloroplast markers.

To examine the molecular affinity of the Yakutian plant with earlier-analyzed samples from Himalaya and America we chose one representative of each Hydrogonium species, except for taxa of the H. gregarium/ cruegeri group, from which all available sequences were used. Oxystegus tenuirostris and Tortella fragilis were selected as outgroup taxa, according to results from Kučera et al. (2013).

The selected sequences were aligned using online MAFFT v7.029b (Katoh \& Toh 2008), employing the Q-INS-i strategy with $20 \mathrm{PAM} / \mathrm{K}=2$ scoring matrix, gap opening penalty set to 1.0 , and offset value set to 0.0 . The resulting alignments were manually inspected for homology problems and manually edited, but these interventions were limited to very obvious cases to ensure maximum reproducibility. Indels were not scored.

The resulting matrix of 21 taxa (alignment length = 1159, 433 variable and 246 parsimony-informative sites; base identities among the analyzed plants of $H$. gregarium s.l. are summarized in Table 1) was analyzed for phylogenetic inference using Bayesian inference (BI) in MrBayes v. 3.2.1 (Ronquist et al. 2012), maximum likelihood (ML) in phyML v. 3.1 (Guindon et al. 2010), and maximum parsimony (MP) using TNT v. 1.1 (Goloboff et al. 2008). In MrBayes we used a gamma model of rate variation across sites sampled across the GTR model space and performed two simultaneous runs, 1 mil. generations in otherwise default settings except for temp $=$ 0.05 . Twenty-five percent of the 10,000 sampled trees were discarded as burn-in and the rest were used for construction of the majority consensus tree. ML analysis used a nucleotide substitution model (GTR) with AIC based on likelihood scores computed in jModeltest 2.1.1 (Darriba et al. 2012); equilibrium frequencies were optimized and the proportion of invariable sites was left to be estimated. Branch support in the ML tree was computed using the Bayesian-like transformation of the

Fig. 1. Hydrogonium gregarium (Mitt.) Jan Kučera and its environment: A - habit, dry, B - habit, wet, C - young gemma, D - mature gemma, E - Vostochnaya Khandyga, river bar, F - light Larix cajanderi Mayr wood at lower river terrace, G - Leontopodium leontopodioides (Willd.) Beauverd from the river bar, $\mathrm{H}$ - Ephedra monosperma C. A. Mey. among Abietinella and Rhytidium at forest edges and openings (solitary plants are Pulsatilla and Euphrasia), I - Tomentypnum falcifolium (Renauld ex Nichols) Tuom., a common component of mesic Larix forest, with Vaccinium vitis-idaea L., J - Larix forest plants (in this place): Arctous alpina (L.) Nied. growing among Hylocomium splendens (Hedw.) Schimp. and Aulacomnium acuminatum (Lindb. \& Arnell) Kindb. 

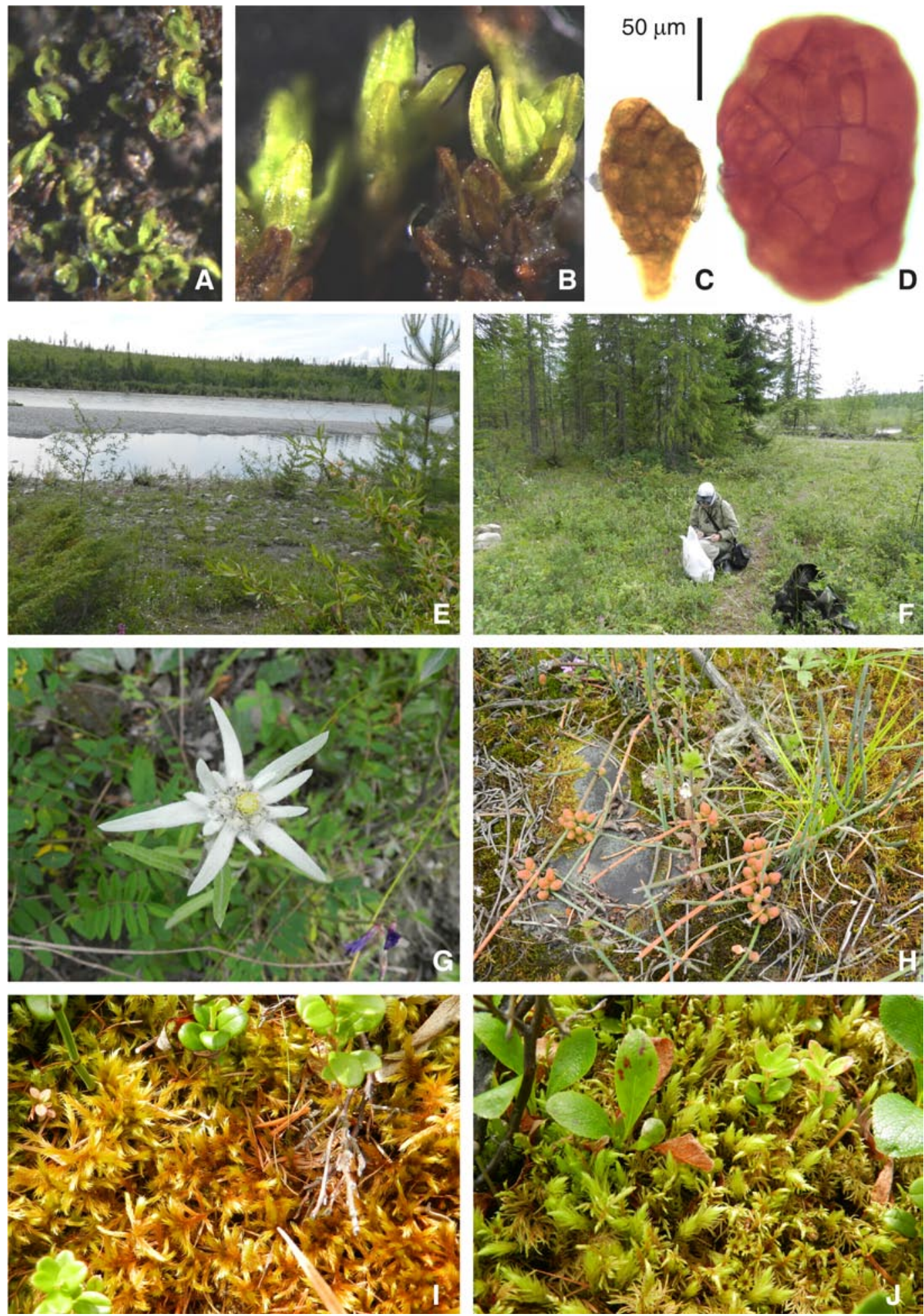
Table 1. Percentage of base identities among the analyzed ITS sequences of Hydrogonium gregarium s.l.

\begin{tabular}{lcccccc}
\hline & JQ890487 & JQ890503 & JQ890505 & KC995170 & JQ890501 & JQ890526 \\
\hline JQ890487 & & 99.1 & 99.3 & 92.2 & 88.9 & 78.5 \\
JQ890503 & 99.1 & & 99.4 & 92.2 & 89.0 & 77.9 \\
JQ890505 & 99.3 & 99.4 & & 92.5 & 89.5 & 78.0 \\
KC995170 & 92.2 & 92.2 & 92.5 & & 85.9 & 74.4 \\
JQ890501 & 88.9 & 89.0 & 89.5 & 85.9 & & 81.4 \\
JQ890526 & 78.5 & 77.9 & 78.0 & 74.4 & 81.4 & \\
\hline
\end{tabular}

approximate likelihood ratio test (aBayes, Anisimova et al. 2011) implemented in phyML. Given the modest dataset, in TNT the most parsimonious trees could be searched using the implicit enumeration (branch-andbound) method; gaps were scored as missing data.

\section{RESULTS}

The topology and clade resolution in trees from Bayesian and ML analyses were identical (Fig. 2). In MP analysis the three most parsimonious trees were found (len $=1739, \mathrm{CI}=0.675, \mathrm{RI}=0.734$ ). The strict consensus is not in conflict with the BI/ ML tree except for separation of a clade consisting of Hydrogonium javanicum and $H$. subcomosum in MP $(\mathrm{BS}=96)$.

The ITS sequence of the newly analyzed Yakutian plant appears in the clade of Himalayan samples of $H$. gregarium. at the same time, $H$. gregarium var. gallinulum represents a sister group to the $H$. gregarium s.str. clade, while the Mexican sample of $H$. gregarium appears together with H. cruegeri from Mexico. This suspicious position, which probably relates to deep coalescence or hybridization events, was discussed in Kučera et al. (2013). In any event, our analysis clearly confirms the identity of the Yakutian plant with H. gregarium s.str.

\section{TAXONOMY}

\section{Hydrogonium gregarium (Mitt.) Jan Kučera}

Figs $3 \& 4$

Taxon 62: 35. 2013. - Tortula gregaria Mitt., J. Proc. Linn. Soc., Bot., Suppl. 1: 29. 1859. - Barbula gregaria (Mitt.) A. Jaeger, Ber. Thätigk. St. Gallischen Naturwiss. Ges. 1871-1872: 424. 1873. - Barbula indica var. gre- garia (Mitt.) R. H. Zander, Cryptog. Bryol. Lichénol. 2: 6. 1981.

Plants small, in moderately dense tufts, yellowish green to brownish green. Stem 5-8 mm, rather evenly foliate with upper leaves gradually slightly larger, central strand well developed. Leaves incurved and somewhat twisted when dry, erect-spreading when wet, $0.9-1.8 \times 0.3-0.6$ $\mathrm{mm}$, oblong-lanceolate with broadened base, rather abruptly contracted to broadly acute leaf tip, keeled in upper part; margins crenulate by papillae on marginal cells, otherwise entire, plane; costa percurrent, strong, ca $80 \mu \mathrm{m}$ wide at base, gradually narrowing distally, in cross section with two stereid bands in lower part of leaf, ventral and dorsal epidermis differentiated; dorsal epidermal cells with prorate ends forming double papillae at cell joints; upper and median laminal cells subquadrate, (7-)8-9 $\mu \mathrm{m}$, basal cells short rectangular, 20-30× 8-12 $\mu \mathrm{m}$, slightly papillose to smooth. Dioicous, sporophytes unknown in Russia. Axillary gemmae by $1-2$, red-brown, ovoid, $120-160 \times 80-100 \mu \mathrm{m}$, multicellular.

DifFERENTIATION. There are two common species in Yakutia that can be macroscopically confused with $H$. gregarium: Barbula unguiculata Hedw. and Streblotrichum convolutum (Hedw.) P. Beauv. Both of them lack axillary gemmae and double papillae at the dorsal costa surface (cf. Fig. 3); S. convolutum moreover produces spherical rhizoidal gemmae and strongly differs in sporophytic characters (yellow seta, revoluble annulus).

Two most similar and most closely related taxa - Hydrogonium cruegeri and H. gregarium var. gallinulum - have not yet been reported from Asia, 


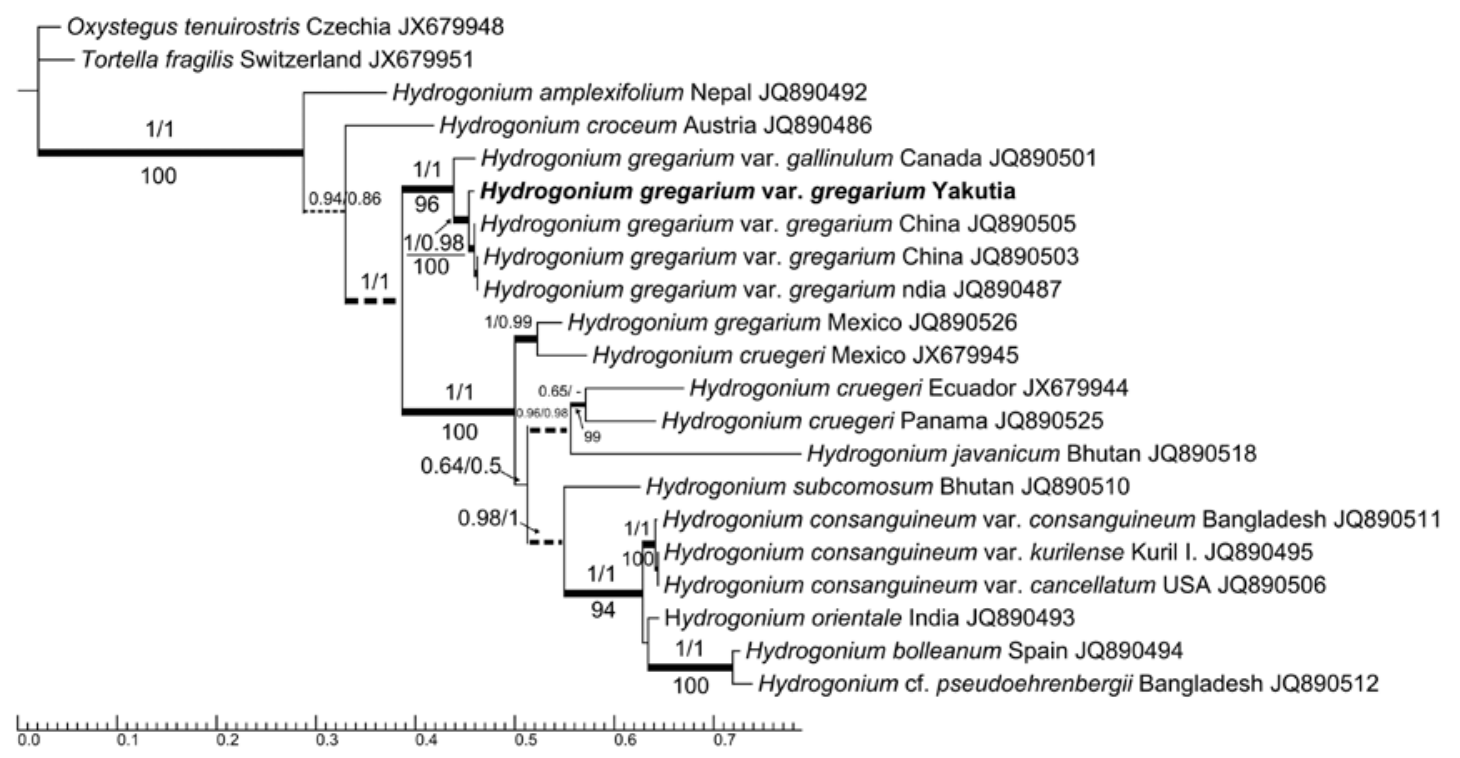

Fig. 2. Phylogenetic relationships (50\% majority consensus tree) from the Bayesian inference of the nrITS dataset. Scale bar below the tree indicates branch length. New accession of Hydrogonium gregarium (Mitt.) Jan Kučera is in bold. Numbers above branches indicate posterior probability from the BI followed by aBayes support values (if $>0.5$ ) from ML analysis; numbers below branches indicate bootstrap values (1000 replications) of MP analysis where applicable. Bold branches indicate clades with $\mathrm{PP} / \mathrm{aBayes}$ values $>0.95$; dotted lines indicate branches not resolved in MP analysis.

but particularly the latter one cannot be ruled out in the region. It differs in having costa ending below the apex and larger lamina cells (10-12 vs. 7-10 $\mu \mathrm{m}$ in var. gregarium). Hydrogonium cruegeri probably broadly overlaps in morphological characters with $H$. gregarium although it usually can be distinguished by its stronger costa, leaf cells on both sides being ampullaceous-mammillose with extremely high papillae (this character has been observed in some specimens of $H$. gregarium as well), and leaf margins being mostly narrowly recurved in the proximal $1 / 3-2 / 3$. It has not yet been shown to occur outside Central to Equatorial South America, but these distribution data need to be viewed with caution as no detailed revision has dealt with the new taxonomic evaluation by Kučera et al. (2013).

Hydrogonium consanguineum var. kurilense (Ignatova \& Ignatov) Jan Kučera, found in Russia only once in the Kuril Islands (Ignatova \& Ignatov, 2009), differs from $H$. gregarium in having mostly less widened leaf bases, mostly clearly recurved leaf margins, and smaller gemmae which are cla- vate to ovate, not beaked though sometimes corniculate, and mostly 50-120 $\times 30-50 \mu \mathrm{m}$. The same characters can also be used for differentiation of H. orientale (F. Weber) Jan Kučera, which typically has still narrower and more recurved leaves.

Hydrogonium amplexifolium (Mitt.) P.C. Chen has costa smooth at the back and mostly smaller, subspherical to ovoid and never beaked gemmae, $(30-) 50-100(-150) \times 50-80 \mu \mathrm{m}$.

Hydrogonium croceum (Brid.) Jan Kučera and $H$. hiroshii (K. Saito) Jan Kučera are typically larger plants with leaves 2-3 mm long, denticulate to strongly dentate at the apex; gemmae, when present, are also beaked and large but with markedly protuberant cells, giving them a grape-shaped appearance.

DISTRIBUTION. Hydrogonium gregarium var. gregarium has been traditionally reported from Indian and Nepali Himalaya (e.g., Gangulee 1972). It is in fact broadly distributed in all Indomalayan countries, S-SE China and Japan (from the latter country reported as Barbula horrinervis K. Saito) 


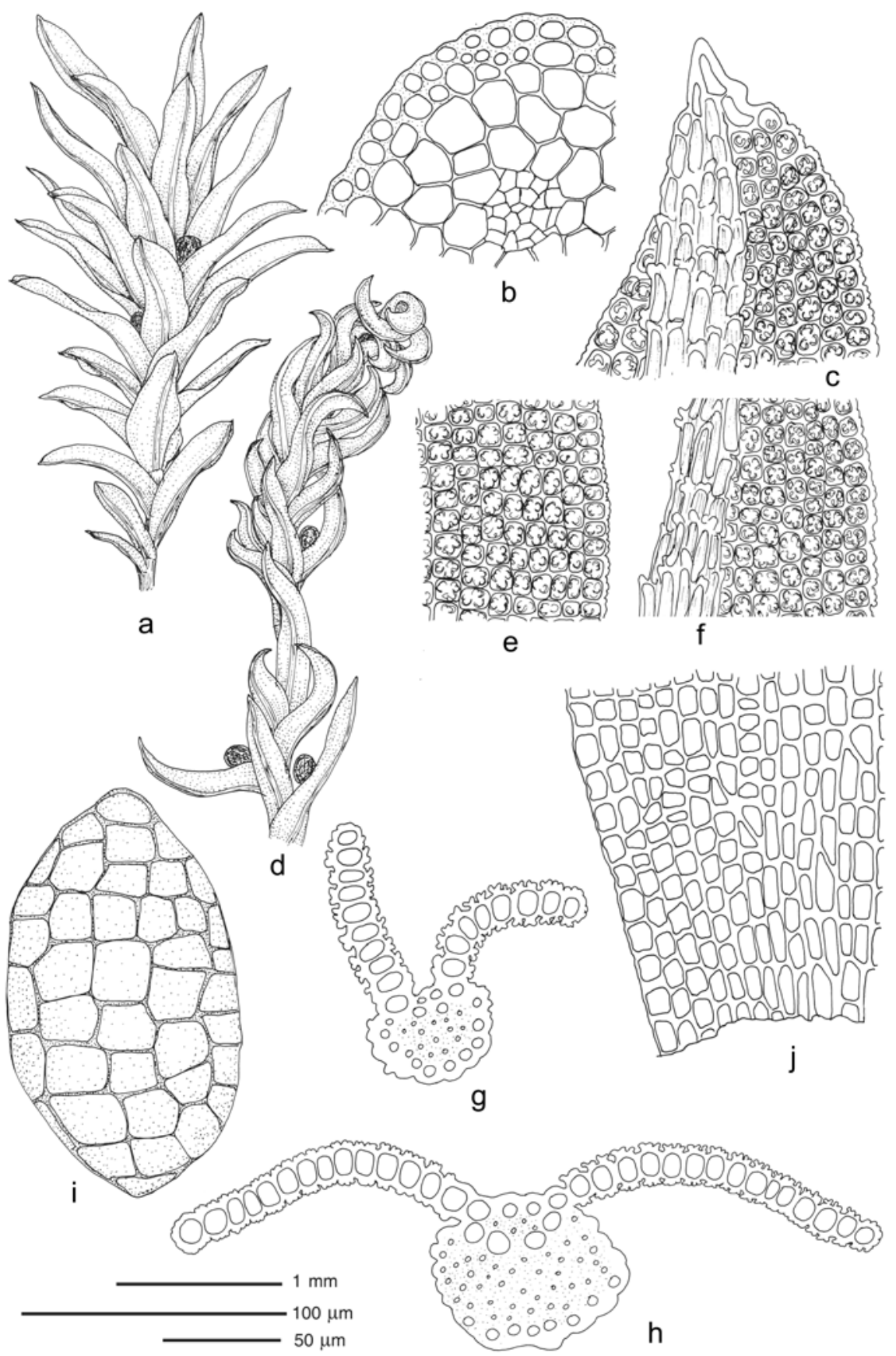

Fig. 3. Hydrogonium gregarium (Mitt.) Jan Kučera (Russia, Yakutia, Ignatov \& Ignatova \#11-2074, MHA): a - habit, wet, $\mathrm{b}$ - stem transverse section, c - upper laminal cells, $\mathrm{d}$ - habit, dry, e - median laminal cells, $\mathrm{f}$ - abaxial surface cells of costa and median laminal cells, g \& h - leaf transverse sections, i - gemma, j - basal laminal cells. Scale bars: $1 \mathrm{~mm}$ for a, d; 100 $\mu \mathrm{m}$ for $\mathrm{b}, \mathrm{c}, \mathrm{e}, \mathrm{f}, \mathrm{j} ; 50 \mu \mathrm{m}$ for $\mathrm{g}, \mathrm{h}, \mathrm{i}$. 


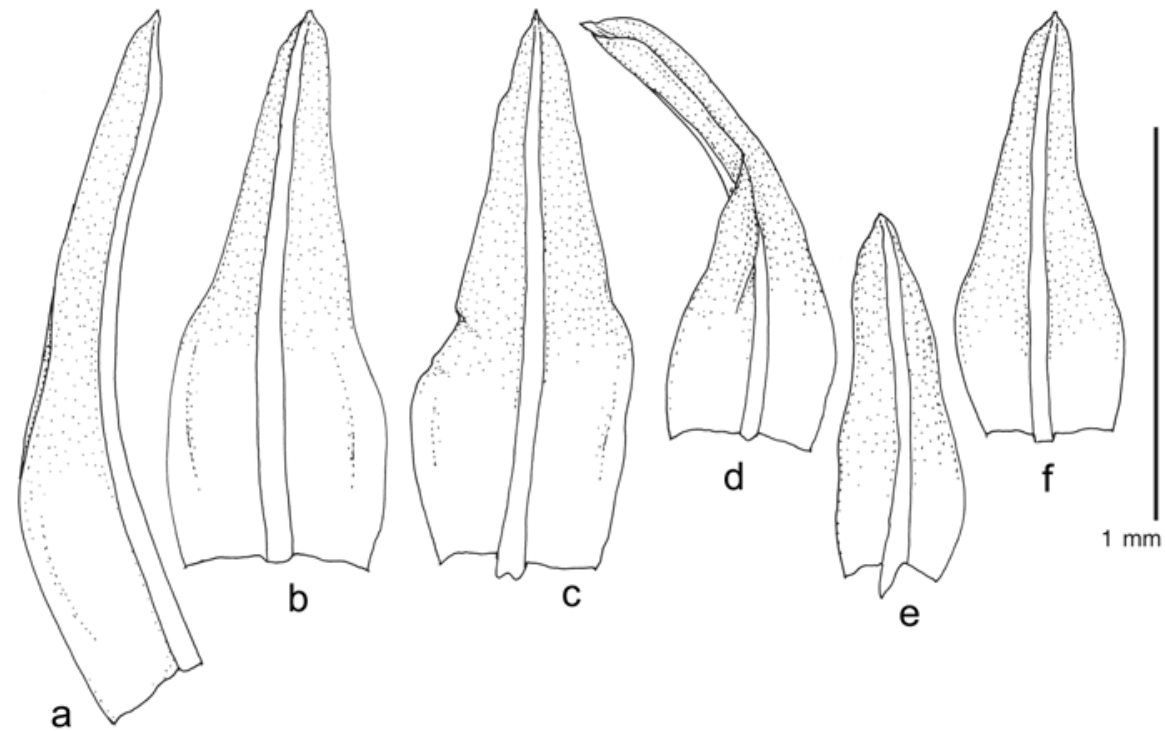

Fig. 4. Hydrogonium gregarium (Mitt.) Jan Kučera (Russia, Yakutia, Ignatov \& Ignatova \#11-2074, MHA): a-c - upper stem leaves, $\mathrm{d}-\mathrm{f}-$ lower stem leaves.

- for a selection of recently revised specimens see Kučera et al. (2013). In the Americas the distribution is imperfectly known due to lumping with H. cruegeri; Kučera et al. (2013) nevertheless accepted one of the Mexican samples. It has also been reported from Alberta Province in Canada (e.g., Zander 2007). Var. gallinulum is known to date only from scattered collections in Alaska, British Columbia and the Northwest Territories. The distance from the closest known locality of $H$. gregarium in Japan is ca $2000 \mathrm{~km}$; without additional data it is not possible to decide whether the Yakutian site is the result of recent long-distance dispersal (e.g., enabled by migratory birds) or has a longer history.

SPECIMEN EXAMINED: RUSSIA. YAKUTIA, Tomponsky District, $c a 2 \mathrm{~km} \mathrm{~W}$ of Teplyj Klyuch, right bank of Vostochnaya Khandyga River, $62^{\circ} 46^{\prime} 19^{\prime \prime} \mathrm{N}$, $136^{\circ} 47^{\prime} 42^{\prime \prime E}, 265 \mathrm{~m}$ a.s.l., soil bank at border of forest and gravelly bar, 7 July 2011, M. Ignatov \& E. Ignatova \#11-2074 (MHA, MW).

\section{PHYTOGEOGRAPHIC CONSIDERATIONS}

The discovery of the principally tropical moss near the 'Pole of Cold' in the Northern Hemisphere indicates that the extreme winter temperatures may not play the principal role in its distribution; rather, humidity and historical connections may be decisive (Ignatov 1993; Ignatov et al. 2000). Some of the accompanying species seem to be largely congruent with this distribution pattern: Ephedra monosperma C. A. Mey. among the vascular plants, Apotreubia sp. among the liverworts (Sofronova 2005), and Haplodontium macrocarpum (Hook.) J. R. Spence among the mosses (Ivanova et al. 2005). More detailed exploration of eastern Siberia can be expected to reveal further interesting extensions of subtropical Asian taxa.

ACKNOWLEDGEMENTS. We are grateful to Elena Ivanova for arranging the Yakutian expedition. We also thank Dr. Olaf Werner for helpful remarks on the manuscript. The study was supported in part by the RFBR 12-04-32061, 13-04-01592.

\section{REFERENCES}

Anisimova M., Gil M., Dufayard J.-F., Dessimoz C. \& GASCUEL O. 2011. Survey of branch support methods demonstrates accuracy, power, and robustness of fast likelihood-based approximation schemes. Syst. Biol. 60: 685-699. 
Darriba D., TABoAda G. L., DoAllo R. \& PosadA D. 2012. jModelTest 2: more models, new heuristics and parallel computing. Nature Methods 9: 772.

GANGUleE H. C. 1972. Mosses of eastern India and adjacent regions. 3. Privately published, Calcutta.

Gardiner A., Ignatov M., Huttunen S. \& Troitsky A. 2005. On resurrection of the families Pseudoleskeaceae Schimp. and Pylaisiaceae Schimp. (Musci, Hypnales). Taxon 54: 651-663.

GOLOBOFF P., FARRIS J. \& NIXON K. 2008. TNT, a free program for phylogenetic analysis. Cladistics 24: 774-786.

Guindon S., Dufayard J.-F., Lefort V., Anisimova M., HordiJK W. \& GASCUEL O. 2010. New algorithms and methods to estimate maximum-likelihood phylogenies: assessing the performance of PhyML 3.0. Syst. Biol. 59: 307-321.

IGNATOV M. S. 1993. Moss diversity patterns on the territory of the former USSR. Arctoa 2: 13-47.

Ignatov M. S., Tan B. C., Iwatsuki Z. \& Ignatova E. A. 2000. Moss flora of the Upper Bureya River (Russian Far East). J. Hattori Bot. Lab. 88: 147-178.

Ignatova E. A. \& Ignatov M. S. 2009. Two new taxa of Pottiaceae (Bryophyta) from the Kuril Islands. Arctoa 18: 135-140.

IsAKova V. G. 2010. Moss flora of the Yana-Adycha Plateau (North-East Yakutia). Arctoa 19: 175-182.

Ivanova E. I., Ignatova E. A., Ignatov M. S., Zolotov V. I. \& KRIVOSHAPKIN K. K. 2005. Listostebelnye mkhi. In: N. S. DANILOVA (ed.), Raznoobrazie rastitelnogo mira Yakutii, pp. 105-125. Sibirskoe Otdelenie RAN, Novosibirsk.

KATOH K. \& TOH H. 2008. Recent developments in the MAFFT multiple sequence alignment program. Briefings Bioinf. 9: 286-298.
KÖCKINGER H. \& KUČERA J. 2007. Barbula amplexifolia (Mitt.) A. Jaeger in Europe. J. Bryol. 29: 33-40.

Koponen T., Ignatova E. A., Kuznetsova O. I. \& IgnaTOV M. S. 2012. The genus Philonotis (Bartramiaceae, Musci) in Russia. Arctoa 21: 21-62.

KRIVOSHAPKIN K. K., IgNATOV M. S. \& IgNATOVA E. A. 2001. $\mathrm{K}$ flore listostebelnykh mkhov Natsionalnogo prirodnogo parka 'Lenskie Stolby' (ustie r. Labyja). In: N. G. SolOMONOV (ed.), Nationalnyj Prirodny Park 'Lenskie Stolby': geologiya, pochvy, rastitelnost, zhivotny mir, ochrana $i$ ispolzovanie, pp. 71-81. Yakutskij Gosudarstvennyj Universitet, Yakutsk.

KuČERA J., KoŠnAR J. \& WeRnER O. 2013. Partial generic revision of Barbula (Musci: Pottiaceae): Re-establishment of Hydrogonium and Streblotrichum, and the new genus Gymnobarbula. Taxon 62: 21-39.

LAZEBNIK O. A. (ed.) 2000. Respublika Sakha (Yakutia). Roskartografia, Yakutsk \& Moscow.

Ronquist F., TeSLenko M., VAN DER MARK P., Ayres D. L., Darling A., Höhna S., Larget B., Liu L., Suchard M. A. \& HuelsenBeCK J. P. 2012. MrBayes 3.2: Efficient Bayesian phylogenetic inference and model choice across a large model space. Syst. Biol. 61: 539-542.

SAITO K. 1975. A monograph of Japanese Pottiaceae (Musci). J. Hattori Bot. Lab. 39: 373-537.

Sofronova E. V. 2005. Pechenochnye mkhi. In: N. S. DANILOVA (ed.), Raznoobrazie rastitelnogo mira Yakutii, pp. 92-104. Sibirskoe Otdelenie RAN, Novosibirsk.

ZANDER R. H. 2007. Barbula. In: FLORA OF NORTH AMERICA Editorial Committee (ed.), Flora of North America north of Mexico, 27: 528-534. Oxford University Press, New York. 